\title{
The Wear Resistance of $\mathrm{Cr}-\mathrm{C}-\mathrm{Al}_{2} \mathrm{O}_{3}$ Composite Deposits Prepared on a $\mathrm{Cu}$ Substrate using $\mathrm{Cr}^{3+}$-based Plating Baths
}

\author{
Ching An HUANG ${ }^{a^{*}}$ and Chin Huo CHUANG ${ }^{\mathrm{b}}$ \\ Department of Mechanical Engineering, Chang Gung University, Taoyuan, 333 Taiwan \\ afehu@mail.cgu.edu.tw ${ }^{1},{ }^{\text {bd}}$ 9822003@stmail.cgu.edu.tw
}

\begin{abstract}
Cr-C- $\mathrm{Al}_{2} \mathrm{O}_{3}$ deposits with different $\mathrm{Al}_{2} \mathrm{O}_{3}$ concentrations were successfully prepared on a $\mathrm{Cu}$ substrate using $\mathrm{Cr}^{3+}$-based electroplating baths. The microstructures of the $\mathrm{Cr}-\mathrm{C}-\mathrm{Al}_{2} \mathrm{O}_{3}$ deposits were examined using optical, scanning and transmission electron microscopes. The hardness values, the corrosion and wear resistance of the $\mathrm{Cr}-\mathrm{C}$ and Cr-C- $-\mathrm{Al}_{2} \mathrm{O}_{3}$ deposited specimens were evaluated. Based on the experimental results, the hardness values of the $\mathrm{Cr}-\mathrm{C}-\mathrm{Al}_{2} \mathrm{O}_{3}$ deposits increased with increasing $\mathrm{Al}_{2} \mathrm{O}_{3}$ concentration in the electroplating bath. According to our microstructure study, $\mathrm{Al}_{2} \mathrm{O}_{3}$ nanoparticles are uniformly distributed within the $\mathrm{Cr}-\mathrm{C}$ deposits after electroplating in a $\mathrm{Cr}^{3+}$-based plating bath. The wear resistance of the $\mathrm{Cr}-\mathrm{C}$-deposited specimens could be noticeably improved by adding $\mathrm{Al}_{2} \mathrm{O}_{3}$ nanoparticles to the deposit. The Cr-C- $\mathrm{Al}_{2} \mathrm{O}_{3}$ deposited specimens, which were prepared in a plating bath with an $\mathrm{Al}_{2} \mathrm{O}_{3}$ concentration of $50 \mathrm{gL}^{-1}$, had a relatively high wear resistance compared to the other specimens.
\end{abstract}

\section{Introduction}

Due to the material's lustre appearance, as well as superior corrosion and wear resistance, $\mathrm{Cr}$ electroplating has been widely used in industrial applications for almost a century. Conventional $\mathrm{Cr}$ electroplating is performed in an electroplating bath containing highly toxic $\mathrm{Cr}^{+6}$ ions [1]. In February of 2003, the Restriction of Hazardous Substances Directive (RoHS) was announced by the European Union. This directive restricts the use of six toxic substances, including $\mathrm{Cr}^{+6}$ ions, in the manufacturing process for electrical and electronic products. Therefore, the development of alternative coatings has become an important topic in recent years [2,3]. Trivalent $\mathrm{Cr}$ electroplating, among all of the alternative options, is considered to have a great potential in replacing conventional hexavalent $\mathrm{Cr}$ electroplating for its relatively low toxicity and high current efficiency [4-6].

In our previous works, we proposed that the hardness value of an as-plated $\mathrm{Cr}-\mathrm{C}$ deposit increased from ca. $780 \mathrm{Hv}$ to ca. $1600 \mathrm{Hv}$ after annealing at $600{ }^{\circ} \mathrm{C}$ for $1 \mathrm{~h}$ [7] or to ca. $1600 \mathrm{Hv}$ through reduction flame heating for $1 \mathrm{~s}$ [8]. However, the cracks in the $\mathrm{Cr}-\mathrm{C}$ deposits severely widened after annealing, reducing the corrosion protection of the coating.

* Corresponding author:gfehu@mail.cgu.edu.tw 
Hence, increasing the mechanical properties of $\mathrm{Cr}-\mathrm{C}$ deposits without weaken the corrosion resistance is important. Composite electroplating may be a useful method for strengthening as-plated $\mathrm{Cr}-\mathrm{C}$ deposits $[9,10]$. In general, ceramic particles, such as $\mathrm{SiC}$ or $\mathrm{Al}_{2} \mathrm{O}_{3}$, are often used as hardening phases to form composite coatings via electroplating [11,12]. The aim of this study is to fabricate $\mathrm{Cr}-\mathrm{C}-\mathrm{Al}_{2} \mathrm{O}_{3}$ composite deposits using $\mathrm{Cr}^{3+}$-based plating baths with different $\mathrm{Al}_{2} \mathrm{O}_{3}$ concentrations. The microstructures, hardness values, and wear resistances of the resulting $\mathrm{Cr}-\mathrm{C}-\mathrm{Al}_{2} \mathrm{O}_{3}$ deposits will be investigated and discussed.

\section{Experimental Procedure}

A commercially pure $\mathrm{Cu}$ disc with a diameter of $20 \mathrm{~mm}$ and a thickness of $2 \mathrm{~mm}$ was used as the substrate for $\mathrm{Cr}-\mathrm{C}-\mathrm{Al}_{2} \mathrm{O}_{3}$ electroplating. Before electroplating, the $\mathrm{Cu}$ substrate was mechanically polished with 600 -grid emery paper, ultrasonically cleaned in an alcohol bath, and dried with an air blaster. The trivalent $\mathrm{Cr}$ plating bath was composed of $0.8 \mathrm{M}$ $\mathrm{CrCl}_{3} \cdot 6 \mathrm{H}_{2} \mathrm{O}$ as the main metal salt, urea as a complex agent and a small amount of buffer salts to maintain a $\mathrm{pH}$ value of 1.1 [7]. $\mathrm{Al}_{2} \mathrm{O}_{3}$ particles with an average size of $100 \mathrm{~nm}$ were added to the plating bath at concentrations of $0,50,100$ and $150 \mathrm{gL}^{-1}$ to produce the $\mathrm{Cr}-\mathrm{C}$ and $\mathrm{Cr}-\mathrm{C}-\mathrm{Al}_{2} \mathrm{O}_{3}$ deposits on the $\mathrm{Cu}$ substrate. A deposit with a thickness of ca. $50 \mu \mathrm{m}$ was prepared with an electroplating current density of $35 \mathrm{Adm}^{-2}$ for $1500 \mathrm{~s}$. The bath temperature was kept at $30 \pm 1{ }^{\circ} \mathrm{C}$ during electroplating. To increase its circulation, the plating bath was stirred with a magnetic stirrer during electroplating.

After electroplating, the surface and cross-sectional morphologies were studied with a scanning electron microscope (SEM; Hitachi S-3000N) and an optical microscope (OM; Olympus $\mathrm{BH} 2-\mathrm{HLSH})$. The hardness values of the $\mathrm{Cr}-\mathrm{C}$ and $\mathrm{Cr}-\mathrm{C}-\mathrm{Al}_{2} \mathrm{O}_{3}$ deposits were measured using a micro-hardness tester (Matsuzawa Digital, Model MXT- $\alpha 7 \mathrm{e}$ ) with a load of $25 \mathrm{~g}$. The mean hardness and standard deviation of a $\mathrm{Cr}-\mathrm{C}$ or $\mathrm{Cr}-\mathrm{C}-\mathrm{Al}_{2} \mathrm{O}_{3}$ deposit were evaluated by measuring at five arbitrary positions that were approximately in the centre of its cross section mounted in epoxy. The microstructures of the as-plated $\mathrm{Cr}-\mathrm{C}$ and $\mathrm{Cr}-\mathrm{C}-\mathrm{Al}_{2} \mathrm{O}_{3}$ deposits were characterised using optical, scanning and transmission electron microscopes (TEM; Philips Tecnai F30).

The wear resistance of the $\mathrm{Cr}-\mathrm{C}$ and $\mathrm{Cr}-\mathrm{C}-\mathrm{Al}_{2} \mathrm{O}_{3}$ deposited specimens was evaluated using a ball-on-plate wear tester, in which a $6 \mathrm{~mm}$ counterpart ball made of steel with a hardness value of ca. $450 \mathrm{Hv}$ was used. During the wear-resistance test, a constant load of $10 \mathrm{~N}$ was applied normally to the $\mathrm{Cr}-\mathrm{C}$ or $\mathrm{Cr}-\mathrm{C} / \mathrm{Al}_{2} \mathrm{O}_{3}$ deposited specimens under an unlubricated condition at $25{ }^{\circ} \mathrm{C}$. The wear-resistance test was conducted with a circular track with a diameter of $3 \mathrm{~mm}$, a frequency of $10 \mathrm{~Hz}$, and a total ground distance of $50 \mathrm{~m}$. The weight-difference value of the $\mathrm{Cr}-\mathrm{C}$ or $\mathrm{Cr}-\mathrm{C}-\mathrm{Al}_{2} \mathrm{O}_{3}$ deposited specimens was measured before and after the wear-resistance test using a scale with a precision of $0.01 \mathrm{mg}$. Optical microscopes was used to examine the surface morphologies of the $\mathrm{Cr}-\mathrm{C}$ and $\mathrm{Cr}-\mathrm{C}-\mathrm{Al}_{2} \mathrm{O}_{3}$ deposited specimen before and after the wear tests.

\section{Results and Discussion}

\subsection{Microstructure Study}

Figs. $1(\mathrm{a}, \mathrm{b})$ show the SEM micrographs of the $\mathrm{Cr}-\mathrm{C}$ and $\mathrm{Cr}-\mathrm{C}-\mathrm{Al}_{2} \mathrm{O}_{3}$ deposit surfaces and their chemical composition analyses, which were performed using an energy-dispersive $\mathrm{x}$-ray spectrometer (EDS). It can be observed that the $\mathrm{Al}_{2} \mathrm{O}_{3}$ nanoparticles, shown in a bright colour, were uniformly distributed on the deposit surface (see Fig. 1(b)). The results 
of the EDS analysis, shown in Fig. 1 (b), show the co-deposition of $\mathrm{Cr}-\mathrm{C}$ and $\mathrm{Al}_{2} \mathrm{O}_{3}$ nanoparticles. Typical nodular surfaces were observed in the $\mathrm{Cr}-\mathrm{C}$ and $\mathrm{Cr}-\mathrm{C}-\mathrm{Al}_{2} \mathrm{O}_{3}$ deposits, but narrow cracks were also found in the $\mathrm{Cr}-\mathrm{C}-\mathrm{Al}_{2} \mathrm{O}_{3}$ deposits.
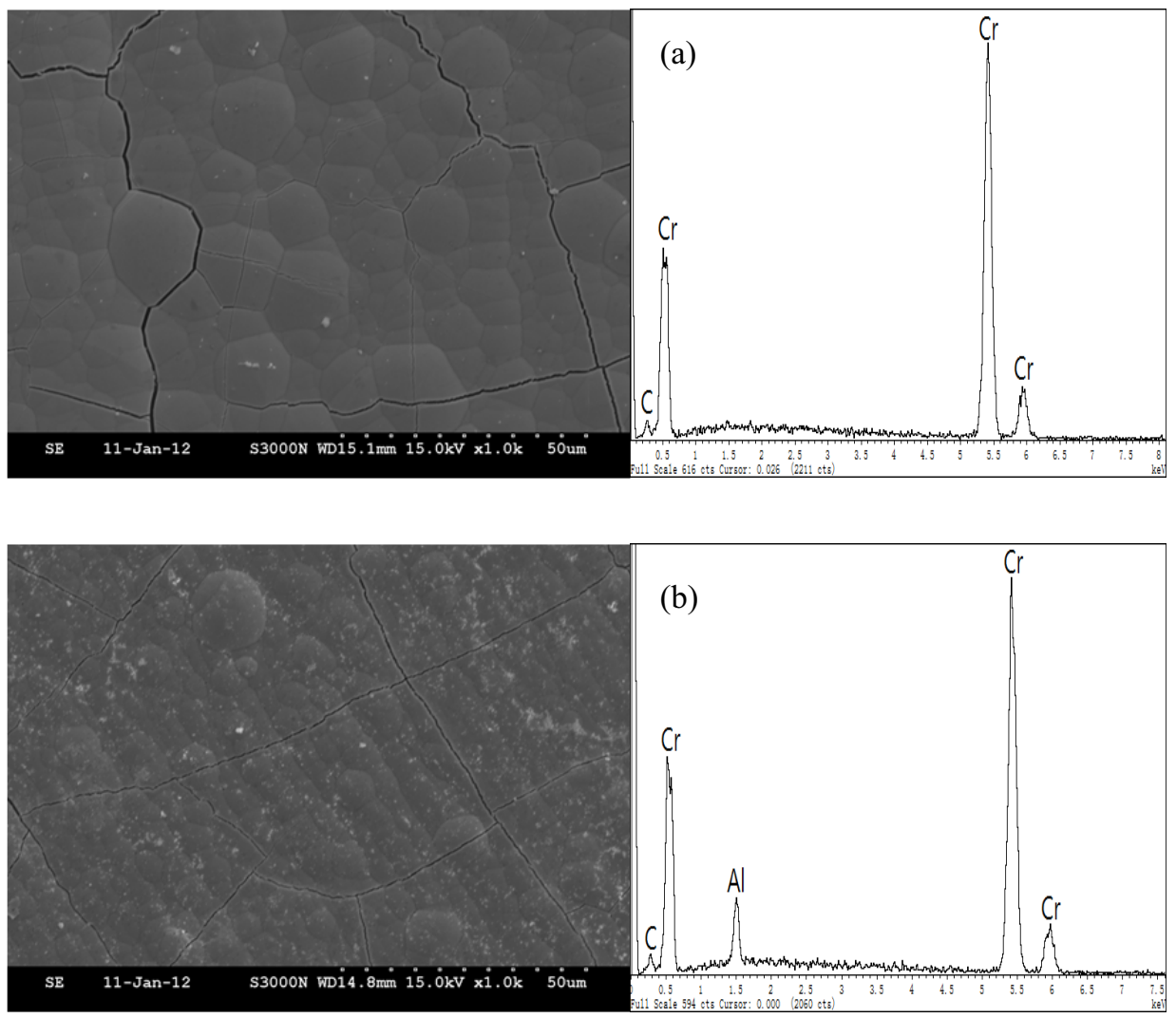

Fig. 1 Surface morphologies and EDS-analysis of (a) $\mathrm{Cr}-\mathrm{C}$ deposits and (b) $\mathrm{Cr}-\mathrm{C}-\mathrm{Al}_{2} \mathrm{O}_{3}$ deposits prepared in an electroplating bath with $50 \mathrm{gL}^{-1} \mathrm{Al}_{2} \mathrm{O}_{3}$.

A TEM micrograph of an as-plated $\mathrm{Cr}-\mathrm{C}-\mathrm{Al}_{2} \mathrm{O}_{3}$ deposit prepared in a plating bath with $50 \mathrm{gL}^{-1} \mathrm{Al}_{2} \mathrm{O}_{3}$ is shown in Fig. 2. $\mathrm{Al}_{2} \mathrm{O}_{3}$ nanoparticles with an average size of $100 \mathrm{~nm}$ can be clearly seen in the deposit. The $\mathrm{Al}_{2} \mathrm{O}_{3}$ nanoparticles in the deposit were uniformly distributed, although a few aggregates of $\mathrm{Al}_{2} \mathrm{O}_{3}$ nanoparticles were found. It can be expected that the hardness of the $\mathrm{Cr}-\mathrm{C}$ deposits could be reinforced via co-deposition of $\mathrm{Al}_{2} \mathrm{O}_{3}$ nanoparticles. 


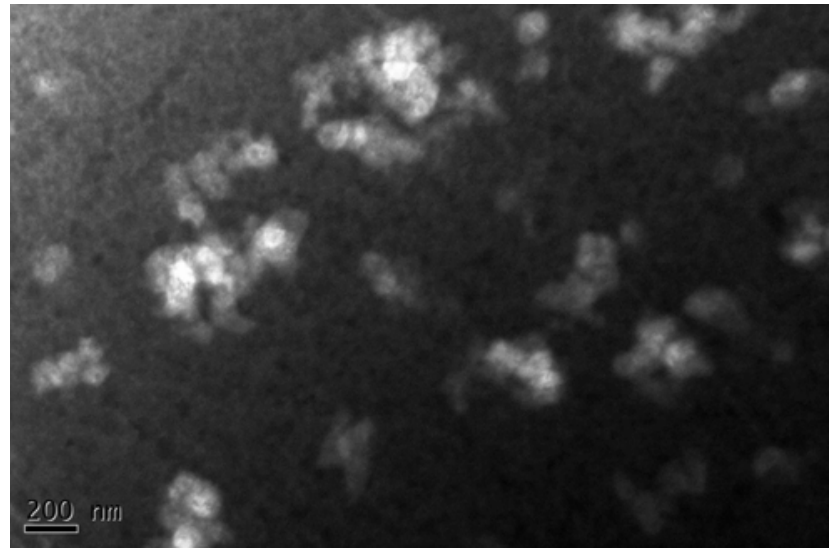

Fig. 2 TEM micrograph of an as-plated $\mathrm{Cr}-\mathrm{C}-\mathrm{Al}_{2} \mathrm{O}_{3}$ deposit prepared from an electroplating bath with $50 \mathrm{gL}^{-1} \mathrm{Al}_{2} \mathrm{O}_{3}$.

\subsection{Hardness Measurement}

Fig. 3 shows the hardness and standard deviation values of the $\mathrm{Cr}-\mathrm{C}-\mathrm{Al}_{2} \mathrm{O}_{3}$ deposits with different $\mathrm{Al}_{2} \mathrm{O}_{3}$ concentrations. The hardness of the as-plated $\mathrm{Cr}-\mathrm{C}$ deposits is $683 \mathrm{Hv}$, whereas the values of 791,814 and $852 \mathrm{Hv}$ were detected for the $\mathrm{Cr}-\mathrm{C}-\mathrm{Al}_{2} \mathrm{O}_{3}$ deposits prepared in the baths with 50,100 and $150 \mathrm{gL}^{-1}$ of $\mathrm{Al}_{2} \mathrm{O}_{3}$, respectively. That is, the hardness values of $\mathrm{Cr}-\mathrm{C}-\mathrm{Al}_{2} \mathrm{O}_{3}$ deposits increased with an increasing $\mathrm{Al}_{2} \mathrm{O}_{3}$ concentration in the $\mathrm{Cr}^{3+}$-based plating bath.

According to our previous study [8], the hardness of the as-plated $\mathrm{Cr}-\mathrm{C}$ deposits can be significantly increased to $1600 \mathrm{Hv}$ after flame heating for $1 \mathrm{~s}$. The wear resistance of the as-plated $\mathrm{Cr}-\mathrm{C}$ deposited specimen could also be obviously improved through flame heating. However, the cracks in the flame-heated $\mathrm{Cr}-\mathrm{C}$ deposits became wider and longer, leading to decrease in their corrosion resistance. In this study, we confirmed that the crack density could be significantly reduced and the crack width could be narrowed in the $\mathrm{Cr}-\mathrm{C}$ deposits in the presence of $\mathrm{Al}_{2} \mathrm{O}_{3}$ nanoparticles. Moreover, the as-plated $\mathrm{Cr}-\mathrm{C}-\mathrm{Al}_{2} \mathrm{O}_{3}$ deposits have a relatively high hardness value, above $790 \mathrm{Hv}$, which is higher than that of fully quench-hardened steels that are used as tool and cutting materials. 


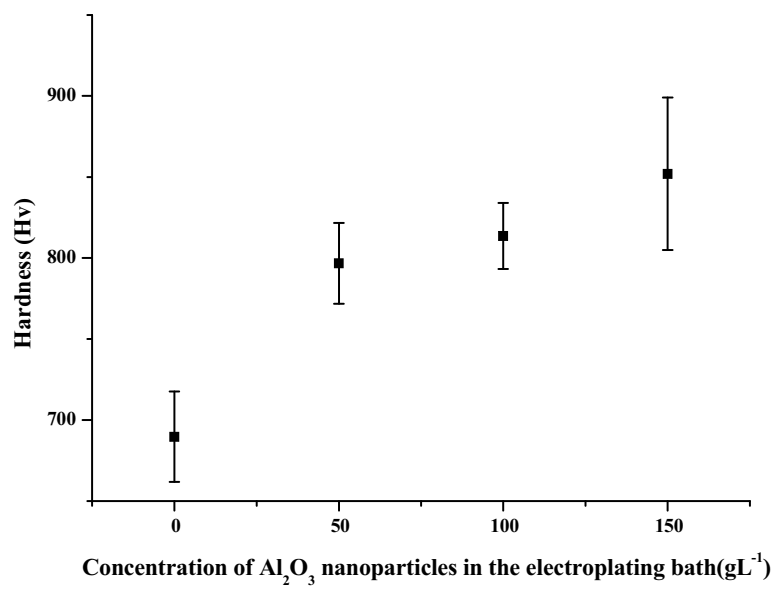

Fig. 3 Hardness values and standard deviations of as-plated $\mathrm{Cr}-\mathrm{C}$ deposits and $\mathrm{Cr}-\mathrm{C}-\mathrm{Al}_{2} \mathrm{O}_{3}$ deposits prepared from electroplating baths with varying concentrations of $\mathrm{Al}_{2} \mathrm{O}_{3}$.

\subsection{Wear Resistance}

The weight-difference values of the $\mathrm{Cr}-\mathrm{C}$ and $\mathrm{Cr}-\mathrm{C}-\mathrm{Al}_{2} \mathrm{O}_{3}$ deposited specimens, before and after the wear-resistance test, are shown in Fig. 4. Clearly, a weight loss of $0.43 \mathrm{mg}$ was detected from the $\mathrm{Cr}-\mathrm{C}$ deposited specimen after the wear-resistance test. However, weight gains were found from the worn $\mathrm{Cr}-\mathrm{C}-\mathrm{Al}_{2} \mathrm{O}_{3}$ deposited specimens prepared from the plating baths with 50 and $100 \mathrm{gL}^{-1}$ of $\mathrm{Al}_{2} \mathrm{O}_{3}$. A slight weight loss of $0.02 \mathrm{mg}$ was detected from the $\mathrm{Cr}-\mathrm{C}-\mathrm{Al}_{2} \mathrm{O}_{3}$ deposited specimens prepared in the electroplating bath with $150 \mathrm{gL}^{-1}$ of $\mathrm{Al}_{2} \mathrm{O}_{3}$. This indicates that the addition of $\mathrm{Al}_{2} \mathrm{O}_{3}$ nanoparticles to the $\mathrm{Cr}-\mathrm{C}$ deposits noticeably increased their wear resistance.

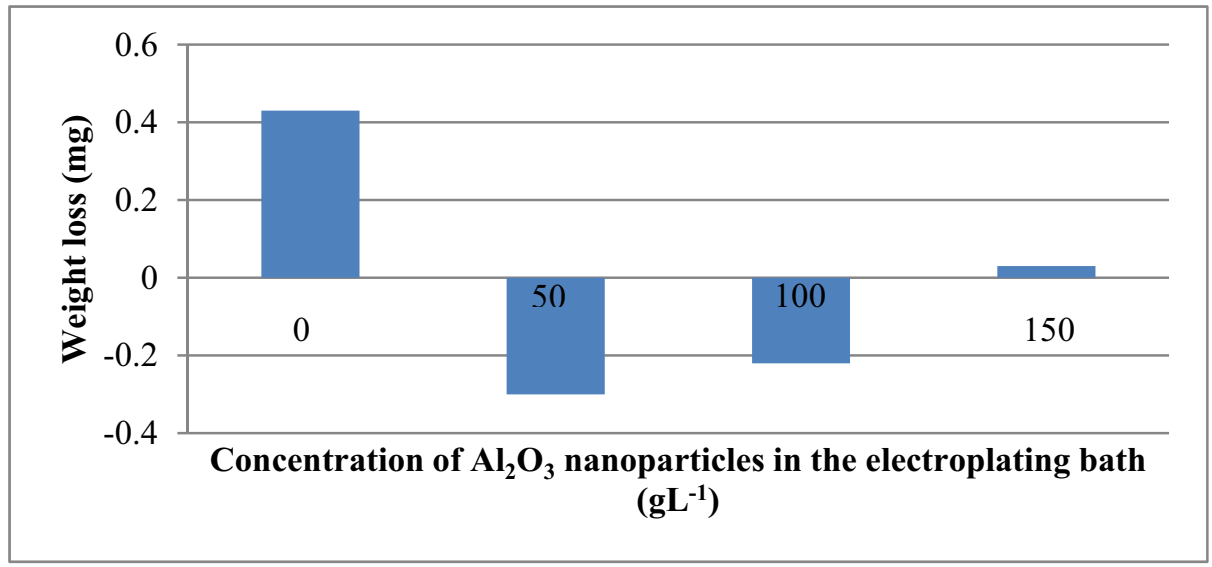

Fig. 4 Weight-difference values of as-plated $\mathrm{Cr}-\mathrm{C}$ and $\mathrm{Cr}-\mathrm{C}-\mathrm{Al}_{2} \mathrm{O}_{3}$ deposited specimens after the wear-resistance test.

The surface morphologies of the $\mathrm{Cr}-\mathrm{C}$ and $\mathrm{Cr}-\mathrm{C}-\mathrm{Al}_{2} \mathrm{O}_{3}$ deposited specimens after the wear-resistance test are shown in Figs. 5(a)-(d). As shown in Fig. 5(a), approximately half 
of the surface of the as-plated $\mathrm{Cr}-\mathrm{C}$ deposits was covered, whereas the other half did not markedly change, revealing a typical nodular surface. However, the nodular surface of the worn $\mathrm{Cr}-\mathrm{C}-\mathrm{Al}_{2} \mathrm{O}_{3}$ deposited specimens was no longer observed; the surface had a circular scratched appearance. Because weight gains could be detected from the $\mathrm{Cr}-\mathrm{C}-\mathrm{Al}_{2} \mathrm{O}_{3}$ deposited specimen prepared in the plating baths with 50 and $100 \mathrm{gL}^{-1}$ of $\mathrm{Al}_{2} \mathrm{O}_{3}$, it can be expected that the circular scratched marks were possibly ground and cold-welded by the steel counterpart.
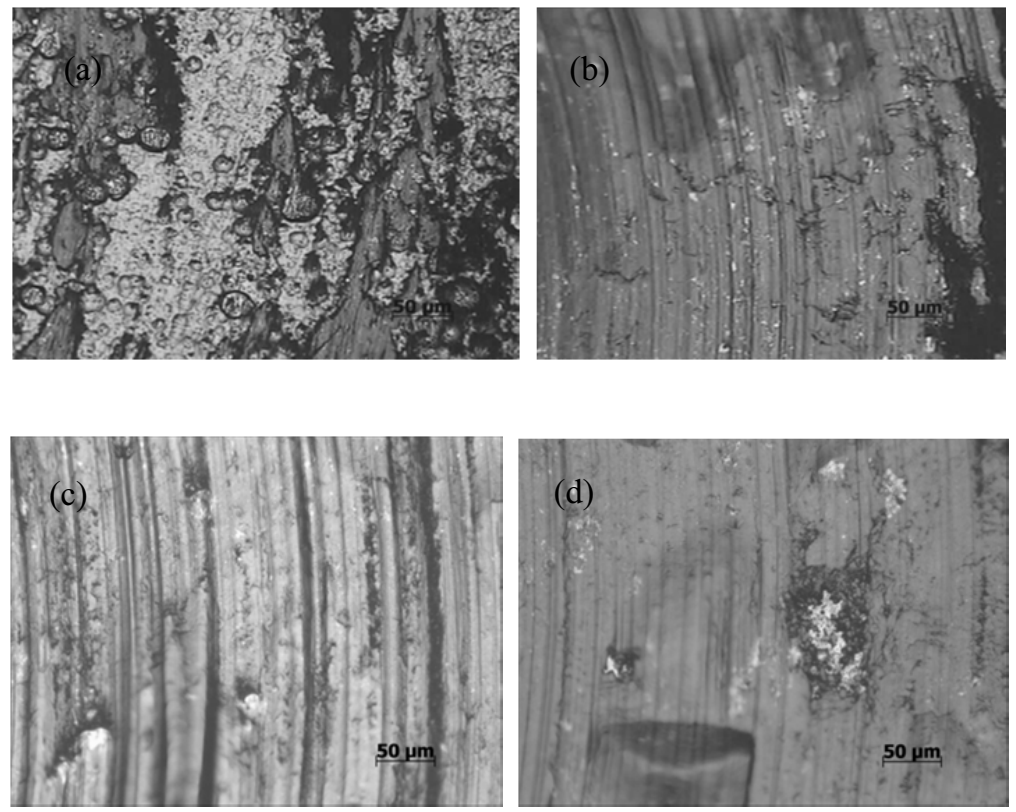

Fig. 5 Surface morphologies of (a) $\mathrm{Cr}-\mathrm{C}$ deposited specimens and $\mathrm{Cr}-\mathrm{C}-\mathrm{Al}_{2} \mathrm{O}_{3}$ deposited specimens prepared in electroplating baths with (b) 50 , (c) 100 , and (d) $150 \mathrm{gL}^{-1} \mathrm{Al}_{2} \mathrm{O}_{3}$, after the wear-resistance test.

The cross-sectional morphologies of the $\mathrm{Cr}-\mathrm{C}$ and $\mathrm{Cr}-\mathrm{C}-\mathrm{Al}_{2} \mathrm{O}_{3}$ deposited specimens after the wear-resistance tests are shown in Figs. 6(a) and (b), in which the specified specimens have either an inferior or superior wear resistance, respectively. The surface profile of the $\mathrm{Cr}-\mathrm{C}$ deposited specimens levelled off significantly after the wear resistance test; however, the worn $\mathrm{Cr}-\mathrm{C}-\mathrm{Al}_{2} \mathrm{O}_{3}$ deposited specimens did not significantly alter their surface profiles. These findings suggest that the addition of $\mathrm{Al}_{2} \mathrm{O}_{3}$ nanoparticles within the $\mathrm{Cr}-\mathrm{C}$ deposits could increase their wear resistance. As shown in Fig. 6(b), a cold-welded layer smeared from the steel counterpart can be found on the surface of the Cr-C- $\mathrm{Al}_{2} \mathrm{O}_{3}$ deposits after the wear-resistance test. This result could explain the weight gain that was detected in the $\mathrm{Cr}-\mathrm{C}-\mathrm{Al}_{2} \mathrm{O}_{3}$ deposited specimens after the wear-resistance test. As shown in Fig. 5(d), some shallow holes were observed in the $\mathrm{Cr}-\mathrm{C}-\mathrm{Al}_{2} \mathrm{O}_{3}$ deposits that were prepared in the electroplating bath containing $150 \mathrm{gL}^{-1} \mathrm{Al}_{2} \mathrm{O}_{3}$ after the wear resistance test. This result implies that some fragments of the $\mathrm{Cr}-\mathrm{C}-\mathrm{Al}_{2} \mathrm{O}_{3}$ deposits were peeled off during the wear-resistance test, resulting in a slight weight loss, though a smeared steel counterpart covered its surface after the wear-resistance test. 

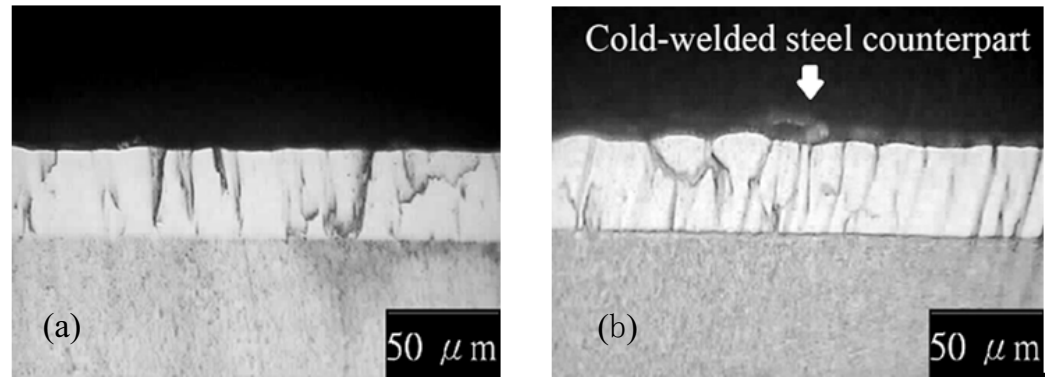

Fig. 6 Cross-sectional morphologies of (a) $\mathrm{Cr}-\mathrm{C}$ deposited specimens and (b) $\mathrm{Cr}-\mathrm{C}-\mathrm{Al}_{2} \mathrm{O}_{3}$ deposited specimens prepared in an electroplating bath with $50 \mathrm{gL}^{-1} \mathrm{Al}_{2} \mathrm{O}_{3}$ after the wear-resistance test.

The wear resistance of the as-plated and anneal-hardened $\mathrm{Cr}-\mathrm{C}$ deposited specimens was evaluated in our previous study [13]. We found that the wear resistance of the as-plated $\mathrm{Cr}-\mathrm{C}$ deposited specimens could be significantly improved after anneal-hardening. A slight weight loss was detected from the anneal-hardened $\mathrm{Cr}-\mathrm{C}$ deposited specimens after the wear-resistance test. In this study, a cold-welded layer, smeared from the steel counterpart, was detected on the surface of the $\mathrm{Cr}-\mathrm{C}-\mathrm{Al}_{2} \mathrm{O}_{3}$ deposited specimens, leading to an increase in their weight. Although the hardness of the anneal-hardened $\mathrm{Cr}-\mathrm{C}$ deposits is much higher than that of the $\mathrm{Cr}-\mathrm{C}-\mathrm{Al}_{2} \mathrm{O}_{3}$ deposits, a slight weight loss was detected from the anneal-hardened $\mathrm{Cr}-\mathrm{C}$ deposited specimens. Because $\mathrm{Al}_{2} \mathrm{O}_{3}$ particles are widely used as an abrasive substance for grinding, the steel counterpart could be abraded by the $\mathrm{Cr}-\mathrm{C}-\mathrm{Al}_{2} \mathrm{O}_{3}$ deposits during the wear-resistance test and cold-welded on the deposited specimens.

\section{Conclusion}

In this study, $\mathrm{Cr}-\mathrm{C}-\mathrm{Al}_{2} \mathrm{O}_{3}$ deposits with different $\mathrm{Al}_{2} \mathrm{O}_{3}$ concentrations could be successfully prepared in $\mathrm{Cr}^{3+}$-based electroplating baths. After electroplating, the corrosion and wear resistance of the $\mathrm{Cr}-\mathrm{C}$ and $\mathrm{Cr}-\mathrm{C}-\mathrm{Al}_{2} \mathrm{O}_{3}$ deposited specimens were investigated. The hardness values of the $\mathrm{Cr}-\mathrm{C}-\mathrm{Al}_{2} \mathrm{O}_{3}$ deposits increased with increasing concentrations of $\mathrm{Al}_{2} \mathrm{O}_{3}$ nanoparticles in the $\mathrm{Cr}^{3+}$-based electroplating baths. The wear resistance of the $\mathrm{Cr}-\mathrm{C}$ deposited specimens can be markedly increased via co-deposition with $\mathrm{Al}_{2} \mathrm{O}_{3}$ nanoparticles. Through-deposit cracks in the $\mathrm{Cr}-\mathrm{C}$ deposits were reduced by adding $\mathrm{Al}_{2} \mathrm{O}_{3}$ nanoparticles to the deposits. The $\mathrm{Cr}-\mathrm{C}-\mathrm{Al}_{2} \mathrm{O}_{3}$ deposited specimens prepared in the electroplating bath with $50 \mathrm{gL}^{-1} \mathrm{Al}_{2} \mathrm{O}_{3}$ had relatively high wear resistances compared to the other specimens.

\section{Acknowledgements}

The authors would like to thank the National Science Council of the Republic of China (ROC) for their support of this work under contract No.: 98-2221-E-182-016-MY2.

\section{References}

1. M. Goldoni, A. Caglieri, D. Poli, M. V. Vettori, M. Corradi, P. Apostoli, A. Mutti, Determination of hexavalent chromium in exhaled breath condensate and environmental air among chrome plating workers, Anal. Chim. Acta, 562 (2006) 229-235. 
2. S. Podgoric, B.J. Jones, R. Bulpett, G. Troisi, J. Franks, Diamond-like carbon/epoxy low-friction coatings to replace electroplated chromium, Wear, 267 (2009) 996-1001.

3. T. Sahraoui, N. Fenineche, G. Montavon, C. Coddet, Alternative to chromium: characteristics and wear behavior of HVOF coatings for gas turbine shafts repair (heavy-duty), J. Mater. Process. Technol., 152 (2004), 43-55.

4. Y.B Song, D.-T Chin, Current efficiency and polarization behavior of trivalent chromium electrodeposition process, Electrochim. Acta, 48 (2002) 349-356.

5. S.C. Kwon, M. Kim, S.U. Park, D.Y. Kim, D. Kim, K.S. Nam, Y. Choi, Characterization of intermediate $\mathrm{Cr}-\mathrm{C}$ layer fabricated by electrodeposition in hexavalent and trivalent chromium baths, Surf. Coat. Technol., 183 ( 2004) 151-156.

6. C.W. Chien, C.L. Liu, F.J. Chen, K.H. Lin, C.S. Lin, Microstructure and properties of carbon-sulfur-containing chromium deposits electroplated in trivalent chromium baths with thiosalicylic acid, Electrochim. Acta, 72 (2012) 74-80.

7. C.A. Huang, Y.W. Liu, C. Yu, C.C.Yang, Role of carbon in the chromium deposit electroplated from a trivalent chromium-based bath, Surf. Cot. Technol., 205 (2011) 3461-3466.

8. C.A. Huang, Y.W. Liu, C.H. Chuang, The hardening mechanism of a chromium-carbon deposit electroplated from a trivalent chromium-based bath, Thin solid films, 517 (2009) 4902-4904.

9. W.X Chen, J.P Tu, H.Y Gan, Z.D Xu, Q.G Wang, J.Y Lee, Z.L Liu, X.B Zhang, Electroless preparation and tribological properties of Ni-P-Carbon nanotube composite coatings under lubricated condition, Surf. Cot. Technol., 160 (2002) 68-73.

10. I. Lyo, H. Ahn, D. Lim, Microstructure and tribological properties of plasma-sprayed chromium oxide-molybdenum oxide composite coatings, Surf. Cot. Technol., 163-164 (2003) 413-421.

11. T. Borkar, S. P. Harimkar, Effect of electrodeposition conditions and reinforcement content on microstructure and tribological properties of nickel composite coatings, Surf. Cot. Technol., 205 (2011) 4124-4134.

12. L. Du, B. Xu, S. Dong, H. Yang, Y. Wu, Preparation, microstructure and tribological properties of nano-A12O3/Ni brush plated composite coatings, Surf. Cot. Technol., 192 (2005) 311-316.

13. C.A. Huang, U.W. Liu, C.H. Chuang, Role of nickel undercoat and reduction-flame heating on the mechanical properties of $\mathrm{Cr}-\mathrm{C}$ deposit electroplated from a trivalent chromium based bath, Surf. Cot. Technol., 203 (2009) 2921-2926. 